Abstracted/indexed in Academic Search Complete, Asia Journals Online, Bangladesh Journals Online, Biological Abstracts, BIOSIS Previews, CAB Abstracts, Current Abstracts, Directory of Open Access Journals, EMBASE/Excerpta Medica, Google Scholar, HINARI (WHO), International Pharmaceutical Abstracts, Open J-gate, Science Citation Index Expanded, SCOPUS and Social Sciences Citation Index;

ISSN: $1991-0088$

\title{
Imatinib inhibits migration of normal human epidermal melanocytes and suppress the phosphorylation of C-kit
}

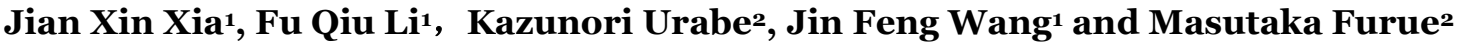 \\ ${ }^{1}$ Department of Dermatology, Second Affiliated Hospital of Jilin University, Changchun 130041, China; ${ }^{2}$ Department \\ of Dermatology, School of Medicine of Kyushu University, Kyushu, Japan.
}

\begin{tabular}{|c|c|}
\hline \multicolumn{2}{|l|}{ Article Info } \\
\hline $\begin{array}{l}\text { Received: } \\
\text { Accepted: } \\
\text { Available Online: }\end{array}$ & $\begin{array}{r}29 \text { May } 2012 \\
4 \text { June } 2012 \\
9 \text { June } 2012\end{array}$ \\
\hline \multicolumn{2}{|c|}{ DOI: $10.3329 /$ bjp.v7i2.10800 } \\
\hline $\begin{array}{l}\text { Cite this article: } \\
\text { Xia JX, Li FQ, Uro } \\
\text { rue M. Imatinib i } \\
\text { normal human } \\
\text { cytes and suppre } \\
\text { tion of C-kit. Bang } \\
\text { 2012; 7: 100-03. }\end{array}$ & $\begin{array}{l}\text { Vang JF, Fu- } \\
\text { migration of } \\
\text { nal melano- } \\
\text { hosphoryla- } \\
\text { J Pharmacol. }\end{array}$ \\
\hline
\end{tabular}

\begin{abstract}
To investigate the inhibitory effect of imatinib on the migration of normal human epidermal melanocytes (NHEM), the growth and differentiation of NHEM were measured by MTT assay. Transwell Cell Migration Assay was performed to determine the migration of NHEM following imatinib treatment. The phosphorylation of c-kit in NHEM after imatinib treatment was measured by Western blot assay. Imatinib at $0.1,1.0$ and $5.0 \mu \mathrm{M}$ could inhibit the SCF $(50 \mathrm{ng} / \mathrm{mL}$ ) induced NHEM migration and suppress the phosphorylation of c-kit in NHEM. The result concluded that imatinib can inhibit SCF induced NHEM migration and suppress the c-kit phosphorylation in NHEM. This provide theoretical basis for the prevention of post-treatment recurrence of nevus spilus.
\end{abstract}

\section{Introduction}

Imatinib mesylate is an inhibitor of tyrosine kinase and recently applied in the treatment of chronic myelogenous leukemia which may be attributed to the blocking of activities of Bcr-abl, V-abl, C-abl, PDGF receptor and c-kit tyrosine kinase (Deininger et al., 1997). Melanocytes have expression of c-kit and c-kit plays important roles in the survival, migration and pigment synthesis of melanocytes (Halaban, 2000). Imatinib could inhibit the proliferation of normal dermal and scleroderma fibroblasts at least partly via the inhibition of the phosphorylation of platelet-derived growth factor receptor, which suggests that imatinib can serve as therapy to limit dermal fibroblast proliferation in scleroderma (Soria et al., 2008). Thus, we speculated that imatinib could inhibit the migration of melanocytes and might be used as a drug for the prevention of posttreatment recurrence of nevus spilus. In the presence study, normal human epidermal melanocytes (NHEM) were collected and cultured and the suppressive effects of imatinib on the growth and migration of NHEM were investigated aiming to explore the potential mechanisms underlying the inhibited growth and migration following imatinib treatment.

\section{Materials and Methods}

\section{Cell line, antibodies and reagents}

C-kit polyclonal antibody (H-300), p-c-kit, $\beta$-Tubulin (D -10) (Santa Cruz, USA), stem cell factor (SCF; PEPRO TECH EC LTD, UK), ECL kit (Amersham Pharmacia biotech), imatinib mesylate (Imatinib; Novartis Japan), NHEM cell line (Cascade biotech, Co., Ltd), HuMediakB2 culture medium, human melanocyte growth supplement (HMGS) (Kurabo, Japan) and cell count kit 8 (Wako Pure Chemical Industries) were used in the present study.

\section{Culture of NHEM and MTT assay of NHEM} proliferation

NHEM was thaw and maintained in HuMedia-kB2 containing 1\% HMGS. NHEM was added into 96-well plate $\left(1 \times 10^{4} /\right.$ well $)$ followed by incubation for 24 


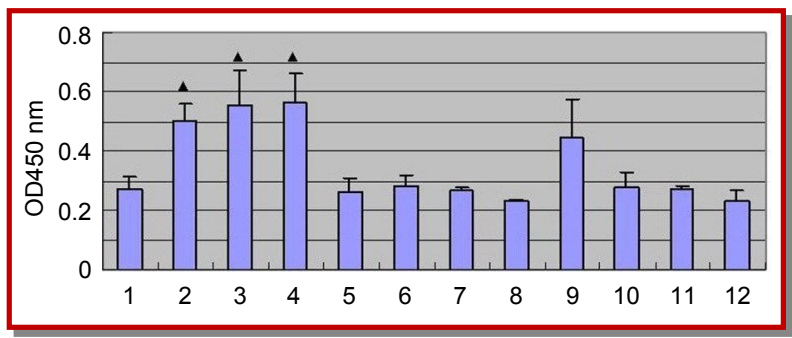

Figure 1: Effects of SCF and imatinib on NHEM proliferation (4 hours after addition of cell count kit 8 reagent). 1: Control group; 2:10 ng/mL SCF; 3:20 ng/mL SCF; $4.5 \mathrm{ng} / \mathrm{mL}$ SCF; 5. .1 $\mu \mathrm{M}$ imatinib; 6.1.0 $\mu \mathrm{M}$ imatinib; 7.5.0 $\mu \mathrm{M}$ imatinib; 8.10.0 $\mu \mathrm{M}$ imatinib; $9.5 \mathrm{ng} / \mathrm{mL} \mathrm{SCF}+0.1 \mu \mathrm{M}$ imatinib; $10.5 \mathrm{ng} / \mathrm{mL} \mathrm{SCF}+$ $1.0 \mu \mathrm{M}$ imatinib; $11.5 \mathrm{ng} / \mathrm{mL} \mathrm{SCF}+5.0 \mu \mathrm{M}$ imatinib; $12.5 \mathrm{ng} /$ $\mathrm{mL} \mathrm{SCF}+10 \mu \mathrm{M}$ imatinib (control group: HuMedia-kB2 containing $10 \%$ FBS alone )

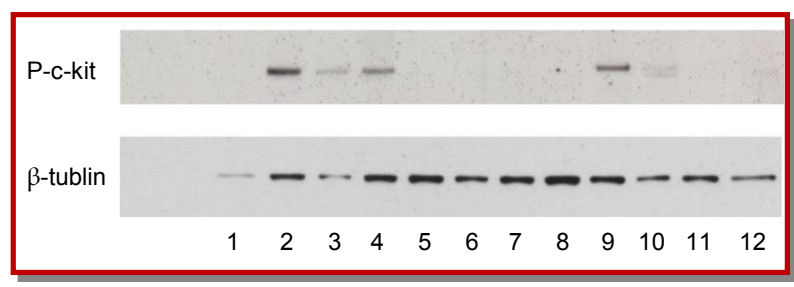

Figure 2: Imatinib inhibits the SCF induced c-kit phosphorylation in NHEM (western blot assay). 1: Control group; 2:10 ng/ $\mathrm{mL} \mathrm{SCF} ; 3: 20 \mathrm{ng} / \mathrm{mL}$ SCF; $4.5 \mathrm{ng} / \mathrm{mL}$ SCF; 5. $0.1 \mu \mathrm{M}$ imatinib; 6.1.0 $\mu \mathrm{M}$ imatinib; 7.5.0 $\mu \mathrm{M}$ imatinib; 8. 10.0 $\mu \mathrm{M}$ imatinib; 9.5 $\mathrm{ng} / \mathrm{mL} \mathrm{SCF}+0.1 \mu \mathrm{M}$ imatinib; $10.50 \mathrm{ng} / \mathrm{mL} \mathrm{SCF}+1.0 \mu \mathrm{M}$ imatinib; $11.5 \mathrm{ng} / \mathrm{mL}$ SCF $+5.0 \mu \mathrm{M}$ imatinib; $12.5 \mathrm{ng} / \mathrm{mL}$ SCF $+10 \mu \mathrm{M}$ imatinib (control group: NHEM without SCF and imatinib)

hours. The medium was refreshed with HMGS free HuMedia-kB2 containing 10\% FBS followed by incubation for 24 hours. Then, SCF at $10 \sim 50 \mathrm{ng} / \mathrm{mL}$ and imatinib at $0.1 \sim 10.0 \mu \mathrm{M}$ were added to each well followed by incubation for 24 hours. At 4 hours before detection, cell count kit 8 solution $(10 \mu \mathrm{L})$ was added and optical density (OD) was measured at 1,2 and 4 hours after incubation at $450 \mathrm{~nm}$.

\section{Detection of effect of imatinib on NHEM migration}

The 24-well Boyden chamber was employed for detection of effect of imatinib on NHEM migration. The fibronectin (FN; $10 \mu \mathrm{g} / \mathrm{mL}$ ) coated $0.8 \mu \mathrm{m}$ pore size insert was added to the upper chamber and then $1 \times 10^{5}$ NHEM and HuMedia-kB2 containing 0.00, 0.1, 1.0, 5.0 and $10.0 \mu \mathrm{M}$ imatinib and 1\% HMGS were supplemented. The lower chamber was divided into 4 groups: Group A: only HuMedia-kB2 medium was added; Group B: HuMedia-kB2 containing $50 \mathrm{ng} / \mathrm{mL}$ SCF was added; Group C: HuMedia-kB2 containing 10\% FBS was added; Group D: HuMedia-kB2 containing 10\% FBS and $50 \mathrm{ng} / \mathrm{mL}$ SCF was added. Five days later, the number of cells migrating from the upper chamber was counted.

\section{Western blot assay of p-c-kit expression in NHEM}

NHEM was maintained in HuMedia-kB2 without
HMGS and 10\% FBS for 24 hours and then the medium was refreshed with HuMedia-kB2 containing 10\% FBS followed by addition of imatinib at different concentrations. Following incubation for $90 \mathrm{~min}, \mathrm{SCF}$ at different concentrations was added to the supernatant followed by incubation for $15 \mathrm{~min}$. Then, $1 \times 10^{6}$ cells were harvested and underwent lysis in $100 \mu \mathrm{L}$ of lysis buffer (0.15 mmol NaCl, 5 mmol EDTA, 1\% Triton X-100, 10 mmol Tris-Cl, $5 \mathrm{mmol}$ DTT, $0.02 \mathrm{mmol}$ PMSF) for 30 min. Centrifugation was performed at $10,000 \mathrm{rpm}$ for 10 min and the supernatant was collected for determination of protein concentration. The protein concentration was adjusted to $0.03 \mathrm{mg} / \mathrm{mL}$ and the protein solution (supernatant) was heated at $70^{\circ} \mathrm{C}$ for $5 \mathrm{~min}$ and then allowed to keep on ice for $5 \mathrm{~min}$. Then, $20 \mu \mathrm{L}$ of protein solution was mixed with loading buffer of appropriate volume and the mixture was subjected to $10 \%$ SDSPAGE $(120 \mathrm{~V}, 60 \mathrm{~min})$. The proteins were then transferred onto PVDF membrane which was then blocked in BSA overnight. The ECL protein detection reagents and ECL protein analysis system were employed for detection. The primary antibody was anti-mouse $\mathrm{p}-\mathrm{Tyr}$ (PY99) (p-c-kit) monoclonal antibody and anti-mouse $\beta$ tubulin (D-10) monoclonal antibody. The PVDF membrane was incubated with primary antibody at 1:1,000 for 1 hours at room temperature and then with HRP conjugated goat anti-mouse secondary antibody (IgG) at 1:5000 for 30 at room temperature. After washing of PVDF membrane, the reagent 1 and 2 were mixed at a ratio of 1:1 and PVDF membrane was treated this mixture for $1 \mathrm{~min}$. Visualization was performed in $\mathrm{X}$ ray film for $3 \mathrm{~min}$.

\section{Statistical analysis}

Microsoft Excel was employed for statistical analysis which was performed with F-test and then with twotailed student "t" test. A value of $p<0.05$ was considered statistically significant.

\section{Results}

Firstly, NHEM was treated with SCF at four concentrations $(10,20,50$ and $100 \mathrm{ng} / \mathrm{mL})$ and the cell proliferation was measured. Results showed the proliferation of NHEM was comparable after treated with SCF at 50 and $100 \mathrm{ng} / \mathrm{mL}$. Thus, SCF at 10, 20 and $50 \mathrm{ng} / \mathrm{mL}$ was used for further experiments. Our results revealed after treatment with $10 \mathrm{ng} / \mathrm{mL}$ SCF for 24 hours, the proliferation of NHEM was significantly increased when compared with untreated NHEM $(p=0.005$; Figure 1). When the SCF concentration was increased to $50 \mathrm{ng} / \mathrm{mL}$, the NHEM proliferation was still dramatically elevated. Thus, in the detection of NHEM migration, only SCF at $50 \mathrm{ng} / \mathrm{mL}$ was used. However, imatinib at $0.1,1.0,5.0$ and $10.0 \mu \mathrm{M}$ had no effect on the proliferation of NHEM (Figure 1). 
Table I

Effect of $50 \mathrm{ng} / \mathrm{mL}$ SCF and imatinib at different concentrations on NHEM migration (number of cells migrating the upper chamber)

\begin{tabular}{|c|c|c|c|c|c|}
\hline & \multirow[t]{2}{*}{ Control group } & \multicolumn{4}{|c|}{ Imatinib concentration $(\mu \mathrm{M})$} \\
\hline & & 0.1 & 1.0 & 5.0 & 10.0 \\
\hline A (Serum free medium) & $13.0 \pm 2.7$ & $7.7 \pm 1.5$ & $6.0 \pm 2.7$ & $2.0 \pm 1.7$ & $3.0 \pm 1.7$ \\
\hline B (50 ng/mL SCF) & $127.0 \pm 9.9 \mathrm{a}$ & $68.7 \pm 7.5$ & $25.3 \pm 1.5$ & $17.0 \pm 3.6$ & $5.7 \pm 1.5$ \\
\hline C (10\% FBS) & $38.3 \pm 7.6$ & $32.7 \pm 6.7$ & $15.0 \pm 7.8$ & $11.0 \pm 1.7$ & $11.7 \pm 1.5$ \\
\hline $\mathrm{D}(10 \% \mathrm{FBS}$ and $50 \mathrm{ng} / \mathrm{mL} \mathrm{SCF})$ & $252.3 \pm 29.4 b$ & $277.3 \pm 17.6$ & $144.6 \pm 3.5$ & $30.0 \pm 2.7$ & $4.3 \pm 1.5$ \\
\hline P1 & & 0.001 & 0.003 & 0.0 & 0.002 \\
\hline P2 & & 0.3 & 0.02 & 0.005 & 0.005 \\
\hline
\end{tabular}

ap= 0.00004: Group B vs Group A; b $=0.00026$ Group D vs Group C; P1: P value in the investigation of effect of imatinib at different concentrations on NHEM migration in Group B; P2: P value in the investigation of effect of imatinib at different concentrations on NHEM migration in Group D

Table II

Imatinib inhibits the SCF induced c-kit phosphorylation in NHEM (western blot assay)

\begin{tabular}{|cccccccccccccc|}
\hline & 1 & 2 & 3 & 4 & 5 & 6 & 7 & 8 & 9 & 10 & 11 & 12 \\
\hline $\begin{array}{c}\text { P-ckit } \\
\begin{array}{c}\text { B- } \\
\text { tublin } \\
\text { Ratio }\end{array}\end{array}$ & 0 & 305946 & 106003 & 159238 & 0 & 0 & 0 & 0 & 243810 & 47885 & 0 & 0 \\
\end{tabular}

1: Control group; 2:10 ng/mL SCF; 3:20 ng/mL SCF; $4.5 \mathrm{ng} / \mathrm{mL}$ SCF; $5.0 .1 \mu \mathrm{M}$ imatinib; $6.1 .0 \mu \mathrm{M}$ imatinib; $7.5 .0 \mu \mathrm{M}$ imatinib; $8.10 .0 \mu \mathrm{M}$ imatinib; $9.5 \mathrm{ng} / \mathrm{mL}$ SCF + $0.1 \mu \mathrm{M}$ imatinib; $10.5 \mathrm{ng} / \mathrm{mL} \mathrm{SCF}+1.0 \mu \mathrm{M}$ imatinib; $11.5 \mathrm{ng} / \mathrm{mL} \mathrm{SCF}+5.0 \mu \mathrm{M}$ imatinib; $12.5 \mathrm{ng} / \mathrm{mL} \mathrm{SCF}+10$ $\mu \mathrm{M}$ imatinib (control group: NHEM without SCF and imatinib)

In the Group A, the number of cells migrating from the upper chamber was extremely small (Table I). In the Group C, there was still small number of cells migrating from the upper chamber. After addition of SCF at 50 $\mathrm{ng} / \mathrm{mL}$ to the lower chamber, the number of NHEM migrating from the upper chamber was markedly increased irregardless of the presence of FBS in the lower chamber (Table I, Figure 1, Figure 2) $(p=0.00004$ Group B vs A; $p=0.00026$ Group D vs C). This result suggests SCF can stimulate the migration of NHEM. After addition of $50 \mathrm{ng} / \mathrm{mL} \mathrm{SCF}$, imatinib could markedly inhibit the SCF induced migration of NHEM as compared to control group (without imatinib), which was in a imatinib concentration dependent manner: The higher the concentration of imatinib, the more obvious the suppression of NHEM migration (Table I).

Cells were harvested and western blot assay was employed to detect the expressions of $\beta$-tubulin and $p$ Tyr (p-c-kit). Results showed, in the absence of SCF, the expression of p-c-kit was very low in NHEM (band 1). After addition of SCF, the phosphorylation of c-kit was marked increased in NHEM (Bands 2, 3, 4). In addition, imatinib could inhibit the SCF induced c-kit phosphorylation (Bands 9, 10, 11, 12), which was in a imatinib concentration dependent manner: The concentration of imatinib, the lower the expression of p-c-kit (Figure 2; Table II).

\section{Discussion}

Nevus spilus is usually treated with laser treatment, pulse treatment, cryotherapy, etc. However, the posttreatment recurrence has been a challenge for dermatologists (Grevelink et al., 1997). The cause of posttreatment recurrence may be related to the migration of melanocytes and the pigment synthesis (Bergamaschi et al., 1993). Melanocytes originate from neural crest and the pigment synthesis in melanocytes is associated with tyrosinase. Thus, we speculated that inhibition of tyrosine kinase may be used to inhibit the growth, migration and pigment synthesis of melanocytes. Imatinib as imatinib mesylate has molecular formula $\mathrm{C}_{29} \mathrm{H}_{31} \mathrm{~N}_{7} \mathrm{O} \cdot \mathrm{CH}_{4} \mathrm{SO}_{3}$ with the molecular weight of 589.7.

Pharmacologically, it can inhibit the tyrosine kinase at cell level and selectively suppress the proliferation and induce the apoptosis of $\mathrm{Bcr}-\mathrm{Abl}$ positive cells, $\mathrm{Ph}$ positive chronic granulocytic leukemia cells and acute lymphoblastic leukemia cells (Druker et al., 1996). Imatinib has been reported to inhibit melanogenesis in vitro (Cario-André et al., 2006). In addition, Imatinib can inhibit the tyrosine kinase of platelet derived growth factor (PDGF) receptor and SCF c-kit receptor, which then abolish the PDGF and SCF induced cellular behaviors. Melanocytes express c-kit and their proliferation is controlled by SCF (Kawakami et al., 2002). 
Thus, in the present cells, NHEM which was isolated from the prepuce of healthy subjects was employed for investigation. The effect of SCF on the NHEM growth and that of imatinib on NHEM migration were investigated. Firstly, we explored the optimal concentration of SCF at which SCF promoted NHEM growth and the optimal concentration of imatinib at which imatinib inhibited NHEM proliferation (unpublished). Our results revealed SCF at $10 \mathrm{ng} / \mathrm{mL}$ could stimulate the NHEM growth and the NHEM growth was comparable after treatment with SCF at 50 and $100 \mathrm{ng} / \mathrm{mL}$. Thus, in the detection of NHEM migration, only $v$ SCF was applied. At the same time, the concentration of imatinib was also determined with which it could inhibit the NHEM proliferation. When the imatinib concentration was higher than $10 \mu \mathrm{M}$, the NHEM proliferation was markedly suppressed. Thus, in the experiment on the NHEM migration, imatinib at $10 \mu \mathrm{M}$ was used which could not inhibit the NHEM proliferation. FN is a main component of basement membrane. Before detection of cell migration, the upper chamber was pre-coated with FN and imatinib was added to the upper chamber and SCF to lower chamber. Our findings indicated SCF could promote the NHEM migration and imatinib could inhibit SCF induced NHEM migration in a concentration dependent manner. To investigate the mechanism underlying the suppression of NHEM migration following imatinib treatment, the p-c-kit expression was measured by western blot assay. Results revealed imatinib could inhibit the c-kit phosphorylation. Thus, we speculate that the suppression of NHEM migration by imatinib may be related to the inhibition of c-kit phosphorylation following imatinib treatment.

\section{References}

Bergamaschi O, Kon S, Doine AI, Ruben MP. Melanin repigmentation after gingivectomy: A 5-year clinical and transmission electron microscopic study in humans. Int J Periodontics Restorative Dent. 1993; 113: 85-92.

Cario-André M, Ardilouze L, Pain C, Gauthier Y, Mahon FX, Taieb A. Imatinib mesilate inhibits melanogenesis in vitro. Br J Dermatol. 2006; 155: 493-94.

Deininger MW, Goldman JM, Lydon N, Melo JV. The tyrosine kinase inhibitor CGP57148B selectively inhibits the growth of BCR-ABL-positive cells. Blood 1997; 90:3691-98.

Druker BJ, Tamura S, Buchdunger E, Ohno S, Segal GM, Fanning S, Zimmermann J, Lydon NB. Effects of a selective inhibitor of the Abl tyrosine kinase on the growth of Bcr-Abl positive cells. Nat Med. 1996; 2: 561-66.

Grevelink JM, van Leeuwen RL, Anderson RR, Byers HR. Clinical and histological responses of congenital melanocytic nevi after single treatment with Q-switched lasers. Arch Dermatol. 1997; 133: 349-53.

Halaban R. The regulation of normal melanocyte proliferation. Pigment Cell Res. 2000; 13: 4-14.

Kawakami T, Soma Y, Kawa Y, Ito M, Yamasaki E, Watabe H, Hosaka E, Yajima K, Ohsumi K, Mizoguchi M. Transforming growth factor beta1 regulates melanocyte proliferation and differentiation in mouse neural crest cells via stem cell factor/KIT signaling. J Invest Dermatol. 2002; 118: 471-78.

Soria A, Cario-André M, Lepreux S, Rezvani HR, Pasquet JM, Pain C, Schaeverbeke T, Mahon FX, Taïeb A. The effect of glivec (imatinib) on scleroderma and normal dermal fibroblasts: A preclinical study. Dermatology 2008; 216: 10917. 